\title{
In vitro biological evaluation of eight different essential oils against Trypanosoma cruzi, with emphasis on Cinnamomum verum essential oil
}

\author{
Camila Maria O Azeredo ${ }^{1}$, Thalita Gilda Santos ${ }^{2}$, Beatriz Helena Lameiro de Noronha Sales Maia ${ }^{2}$ \\ and Maurilio José Soares ${ }^{1 *}$
}

\begin{abstract}
Background: Essential oils (EOs) are complex mixtures of secondary metabolites from various plants. It has been shown that several EOs, or their constituents, have inhibitory activity against trypanosomatid protozoa. Thus, we analyzed the biological activity of different EOs on Trypanosoma cruzi, as well as their cytotoxicity on Vero cells.

Methods: The following EOs were evaluated on T. cruzi epimastigote forms: Cinnamomum verum, Citrus limon, Cymbopogon nardus, Corymbia citriodora, Eucalyptus globulus, Eugenia uniflora, Myrocarpus frondosus, and Rosmarinus officinalis. Inhibitory activity against $T$. cruzi $\left(\mathrm{IC}_{50} / 24 \mathrm{~h}\right)$ and cytotoxicity against Vero cells $\left(\mathrm{CC}_{50} / 24 \mathrm{~h}\right)$ were evaluated by the MTT assay. The EO of C. verum was selected for further evaluation against trypomastigotes and intracellular amastigotes, as well as on parasite metacyclogenesis. Constituents of C. verum EO were identified by GC-MS. One-way ANOVA statistical analysis was performed with GraphPad version 5.01.

Results: Cinnamomum verum EO was the most effective against T. cruzi epimastigotes $\left(\mid C_{50} / 24 \mathrm{~h}=24.13 \mu \mathrm{g} / \mathrm{ml}\right)$, followed by Myrocarpus frondosus $\left(I C_{50} / 24 \mathrm{~h}=60.87 \mu \mathrm{g} / \mathrm{ml}\right)$ and Eugenia uniflora $\left(I C_{50} / 24 \mathrm{~h}=70 \mu \mathrm{g} / \mathrm{ml}\right)$. The EOs of C. citriodora, E. globulus, and R. officinalis showed no activity at concentrations up to $300 \mu \mathrm{g} / \mathrm{ml}$. Incubation of T. cruzi metacyclic trypomastigotes and intracellular amastigotes with C. verum EO resulted in $I C_{50} / 24 \mathrm{~h}$ values of $5.05 \mu \mathrm{g} / \mathrm{ml}$ and $20 \mu \mathrm{g} / \mathrm{ml}$, respectively. Therefore, trypomastigotes are more susceptible than epimastigotes, with selectivity index (SI) about 4.7-fold higher ( 9.78 and 2.05, respectively). Analysis of C. verum EO by GC-MS showed mainly (E)-cinnamaldehyde (81.52\%) and eugenol (16.68\%).
\end{abstract}

Conclusions: $C$. verum essential oil is effective against T. cruzi (epimastigotes, trypomastigotes and amastigotes) and interferes with the parasite differentiation process in vitro. Thus, it represents a strong candidate for further studies to improve its activity on pathogenic trypanosomatids.

Keywords: Cinnamon, Cinnamomum verum, Essential oil, Trypanosoma cruzi

\section{Background}

Chagas disease, caused by the flagellate protozoan Trypanosoma cruzi, is a chronic disease that occurs mainly in Latin America. It is estimated that 7-8 million people are infected worldwide [1]. Most infected people live in endemic areas, comprising 21 Latin America countries [1]. Chagas disease is technically considered a zoonosis, as the natural reservoirs are marsupials and placental

\footnotetext{
* Correspondence: maurilio@tecpar.br

'Laboratory of Cell Biology, Carlos Chagas Institute/Fiocruz, Rua Prof. Algacyr Munhoz Mader 3775, Cidade Industrial, 81350-010 Curitiba, PR, Brazil

Full list of author information is available at the end of the article
}

mammals. The disease in humans results from the invasion of natural ecotopes and the establishment of vectors in human dwellings in endemic areas because of poor socio-economic conditions in most rural populations [2].

T. cruzi is naturally transmitted by blood-sucking insects of the subfamily Triatominae (Hemiptera: Reduviidae). Human infection occurs usually by insect bite, oral transmission, blood transfusion, or congenital transmission [2-4]. Transmission through blood transfusion, congenitally, and with intense international migration, has led to spread of

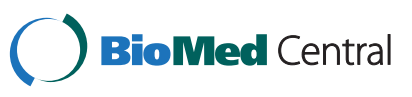


the disease to non-endemic regions, such as United States and Western Europe [2].

Two drugs emerged in the late $1960 \mathrm{~s}$ for the treatment of Chagas disease: benznidazole (Rochagan in Brazil and Radanil in Argentina, from Roche) and nifurtimox (Lampit, from Bayer). These two drugs are still the only ones available for Chagas disease. Both drugs were originally recorded for treatment of the acute phase of Chagas disease, but are currently used in both acute and initial chronic phases [2,5]. However, these chemotherapeutic drugs do not completely fill the World Health Organization (WHO) criteria for an ideal drug, which are: (i) parasitological cure in acute and chronic cases of infection, (ii) effectiveness in a single dose or a few doses, (iii) accessibility to patients (low cost and easy to achieve), (iv) no teratogenic or side effects, (v) no need for hospitalization of patients for treatment, and (vi) without showing resistance or induction of resistance to the etiological agent [6]. Furthermore, efficacy in the acute phase varies with the geographical area, probably because of differences in susceptibility between different strains of T. cruzi [2].

Maintenance of new cases in endemic regions and the recent spread of the disease into non-endemic regions point towards the need to find drugs that are effective both in treatment of disease and prophylaxis of $T$. cruzi in blood banks. Various drugs for the treatment of parasitic diseases have been extracted from plants or synthesized from vegetal prototypes $[7,8]$. Therefore, the study of extracts and compounds with biological activity isolated from plants used in folk medicine is promising in the search for compounds with potential for the prophylaxis of Chagas disease.

Essential oils (EOs) are complex mixtures of secondary metabolites isolated from various plants, which may be synthesized by all plant organs. In these mixtures there are 20-60 constituents at different concentrations, but usually only 2-3 major constituents determine the biological properties of the EO [9]. Essential oils and their constituents present a broad pharmacological spectrum, and are used as antimicrobials, analgesics, sedatives, anti-inflammatory, and anti-spasmodic drugs, as well as anthelmintics and antiprotozoals [6,9-13].

It has been recently shown that several EOs, or their constituents, have inhibitory activity against trypanosomatid protozoa [6,14-22]. However, most studies in $T$. cruzi evaluated the inhibitory activity only on culture epimastigotes and blood trypomastigotes. The data are sparse on the effect of EOs, or their main constituents, on cell differentiation (metacyclogenesis) and on $T$. cruzi intracellular amastigotes. Thus, we have analyzed the effect of different EOs, with emphasis on Cinnamomum verum $\mathrm{EO}$, on epimastigotes, trypomastigotes, and amastigotes, as well as on the process of differentiation in vitro (metacyclogenesis) of T. cruzi.

\section{Methods}

Essential oils (EOs), (E)-cinnamaldehyde and Benznidazole Essential oils of Cinnamomum verum (formerly Cinnamomum zeylanicum; Lauraceae; cinnamon) bark, Citrus limon (Rutaceae; lemon), Cymbopogon nardus (Poaceae; citronella grass), Corymbia citriodora (formerly Eucalyptus citriodora; Myrtaceae; lemon eucalyptus), Eucalyptus globulus (Myrtaceae; blue gum), Eugenia uniflora (Myrtaceae; pitanga), Myrocarpus frondosus (Fabaceae; cabreúva), and Rosmarinus officinalis (Lamiaceae; rosemary) were purchased from QUINARI Cosmetic and Fragrances Inc. (Maringá-PR, Brazil). EOs from cinnamon and lemon eucalyptus were from lot 05209; EOs of pitanga, blue gum, cabreúva, and lemon were from lot 022186; citronella grass EO was from lot 519/520; and rosemary EO was from lot 022185. All EOs were valid until August 2012 and used from 20112012. Benznidazole and (E)-cinnamaldehyde were purchased from Sigma-Aldrich (St Louis, MO, USA).

EOs, (E)-cinnamaldehyde and benznidazole were first diluted in dimethylsulfoxide (DMSO) at $100 \mathrm{mg} / \mathrm{ml}$ for EOs, $50 \mathrm{mg} / \mathrm{ml}$ for benznidazole $(192.14 \mathrm{mM})$, and $13.216 \mathrm{mg} / \mathrm{ml}(100 \mathrm{mM})$ for $(E)$-cinnamaldehyde (first stock). For use, the first stock was diluted 1:50 (benznidazole) or 1:100 (EOs and cinnamaldehyde) in either LIT (liver infusion tryptose) or RPMI-1640 (Sigma-Aldrich) media (second stock). Therefore, DMSO was diluted to $1 \%$, ensuring that its final concentration in the experiments never exceeded $0.5 \%$, a concentration that is not harmful to parasites and Vero cells. These stocks were stored at $4^{\circ} \mathrm{C}$ in the dark, to avoid degradation [23]. The second stock was prepared minutes before use.

\section{Chemical composition of Cinnamomum verum essential oil}

Gas chromatography-mass spectrometry (GC-MS) analysis was performed using a Shimadzu GC-2010 gas chromatograph coupled with GCMS-QP2010 Plus equipped with auto sampler (model AOC-20i, Shimadzu, Columbia, MD, USA) and GC-MS Solution software. Analysis was performed with a Rtx-5MS capillary column (30 $\mathrm{mm} \times$ $0.25 \mathrm{~mm} \times 0.25 \mu \mathrm{m}$ ), using temperature programmed condition from $60^{\circ} \mathrm{C}$ to $250^{\circ} \mathrm{C}$ at $3^{\circ} \mathrm{C} / \mathrm{min}$. Analysis conditions were: injector temperature $250^{\circ} \mathrm{C}$, ion source interface temperature $300^{\circ} \mathrm{C}$, analysis of masses between $40-350 \mathrm{~m} / \mathrm{z}$, electron impact at $70 \mathrm{eV}$, column head pressure at constant pressure of $59 \mathrm{kPa}$, column flow $1.02 \mathrm{ml} / \mathrm{min}$, gas linear velocity: $36.8 \mathrm{~cm} / \mathrm{s}$, carrier gas: helium, injected volume: $1 \mu \mathrm{l}$ (1\% dilution in hexane) in split mode (ratio 1:10). Constituents of the C. verum essential oil were identified by comparing their mass spectral pattern and retention indices (RI) relative to a standard $n$-alkane series $\left(\mathrm{C}_{9}-\mathrm{C}_{24}\right)$ with those given in the literature [24] and the Wiley 138 and Nist 98 databases. 


\section{Evaluation of EO activity on T. cruzi epimastigotes}

Epimastigotes (strain Dm28c) were maintained at $28^{\circ} \mathrm{C}$ in LIT medium supplemented with $10 \%$ fetal calf serum (FCS), with weekly passages. For the screening of EO activity, epimastigotes were collected from cultures at the mid log phase of growth (3-days-old). Parasite concentration was adjusted to $1 \times 10^{7} \mathrm{cells} / \mathrm{ml}$ and $180 \mu \mathrm{l} /$ well were added to a 96 well plate $\left(1.8 \times 10^{6}\right.$ parasites/well $)$. Then $20 \mu \mathrm{l}$ of compounds (final concentration: $5-300 \mu \mathrm{g} / \mathrm{ml}$ for EOs, $0.26-39.65 \mu \mathrm{g} / \mathrm{ml}[2-300 \mu \mathrm{M}]$ for $(E)$-cinnamaldehyde, and $6.25-150 \mu \mathrm{g} / \mathrm{ml}[0.024-0.576 \mathrm{mM}]$ for benznidazole) were added to each well. In control wells, $20 \mu \mathrm{l}$ of culture medium were added without the compounds. The plates were incubated for $24 \mathrm{~h}$ at $28^{\circ} \mathrm{C}$ and then $50 \mu \mathrm{l}$ of MTT (at $10 \mathrm{mg} / \mathrm{ml}$ in PBS) was added to each well (final concentration: $2 \mathrm{mg} / \mathrm{ml}$ per well). The plates were wrapped in aluminum foil, incubated for $3 \mathrm{~h}$ at $37^{\circ} \mathrm{C}$ and then centrifuged at $475 \mathrm{~g}$ for $10 \mathrm{~min}$. The supernatant was removed by abrupt plate inversion. Then $20 \mu \mathrm{l}$ of $10 \%$ SDS in $0.01 \mathrm{M} \mathrm{HCl}$ was added and the parasites were resuspended by gently tapping the plates. The plates were then incubated at $37^{\circ} \mathrm{C}$ for $1 \mathrm{~h}$. Thereafter, $80 \mu \mathrm{l}$ of pure DMSO was added to all wells to solubilize the formazan crystals. Optical density (OD) was read at $550 \mathrm{~nm}$ in an ELISA reader (Biotek model ELx800; Biotek, Winooski, VT, USA). Mean of at least two independent experiments was used to calculate the $\mathrm{IC}_{50} / 24 \mathrm{~h}$ using Microsoft Excel software by linear correlation. Each experiment was performed in triplicate.

\section{Evaluation of EO activity on T. cruzi metacyclic trypomastigotes}

Purified metacyclic trypomastigotes were obtained in vitro after nutritional stress in TAU3AAG medium, as previously described [25]. Briefly, $150 \mathrm{~cm}^{2}$ bottles were inoculated with $5 \times 10^{6}$ epimastigotes $/ \mathrm{ml}$ and after $72 \mathrm{~h}$ at $28^{\circ} \mathrm{C}$ metacyclic trypomastigotes were released into the supernatant. The cells were collected and purified by passage through an affinity column containing DEAE cellulose resin equilibrated with phosphate-saline-glucose buffer (PSG: $47.47 \mathrm{mM} \mathrm{Na} \mathrm{HPO}_{4}, 2.5 \mathrm{mM} \mathrm{NaH} \mathrm{PO}_{4} \cdot \mathrm{H} 2 \mathrm{O}$, $36.76 \mathrm{mM} \mathrm{NaCl}, 55.5 \mathrm{mM}$ glucose). After purification, the concentration of trypomastigotes was adjusted to $5 \times 10^{6}$ cells $/ \mathrm{ml}$ and they were distributed into 24 -well plates containing TAU3AAG medium with different concentrations $(0-20 \mu \mathrm{g} / \mathrm{ml})$ of C. verum EO. Cell lysis was determined after $24 \mathrm{~h}$ by counting parasite density with a Neubauer chamber. This density was used to calculate the $\mathrm{IC}_{50} / 24 \mathrm{~h}$ (concentration leading to 50\% cell lysis). The experiment was performed in triplicate.

\section{Evaluation of EO activity on T. cruzi amastigotes}

Vero cells (ATCC: CCL-81) were kept at $37^{\circ} \mathrm{C}$ in a humidified $5 \% \mathrm{CO}_{2}$ incubator, in $25 \mathrm{~cm}^{2}$ culture flasks containing
RPMI-1640 medium pH 7.4 supplemented with $2.5 \%$ FCS, $2 \mathrm{mM}$ L-glutamine, $10 \mu \mathrm{g} / \mathrm{ml}$ streptomycin and $10 \mu \mathrm{g} / \mathrm{ml}$ penicillin. For the experiments, the cells were seeded into 24-well plates and then infected with trypomastigotes at a 10 parasites/cell ratio. After $4 \mathrm{~h}$ the monolayers were washed with PBS to remove non-internalized parasites and kept for $12 \mathrm{~h}$ at $37^{\circ} \mathrm{C}$ in $1 \mathrm{ml} \mathrm{RPMI} / 2.5 \%$ FCS in a $5 \% \mathrm{CO}_{2}$ humidified atmosphere. After that, the EOs were added to the RPMI medium at different concentrations $(5-20 \mu \mathrm{g} / \mathrm{ml})$ and the plates were incubated for $24 \mathrm{~h}$. The cells were then stained with Giemsa and the whole well (total of nine fields) was photographed in a Nikon TE300 inverted light microscope, with a $20 \times$ objective.

Amastigote counting was performed using ImageJ software, observing the percentage of infected cells, the number of amastigotes/cell, and the total number of amastigotes/ well. Density of amastigote population was calculated dividing the total number of amastigotes/well by the well area $\left(201 \mathrm{~mm}^{2}\right)$. The percentage of inhibition (\%I) was calculated according to Guru et al. (1989) [26], as modified by Lakshmi and collaborators (2007) [27], using the following formula: $\% \mathrm{I}=100-(\mathrm{T} / \mathrm{C} \times 100)$, where $\mathrm{T}$ is the total number of intracellular amastigotes in treated cells and $\mathrm{C}$ is the total number of intracellular amastigotes in control cells. The $\mathrm{IC}_{50} / 24 \mathrm{~h}$ value (concentration that inhibits proliferation of intracellular amastigotes by 50\%) was estimated from the\% I value with the Microsoft Excel software by linear correlation. Statistical analysis (one-way ANOVA) of the data was performed using the software GraphPad Prism Version 5.01 and data with $\mathrm{p}<0.05$ were considered significantly different. The experiment was performed in triplicate.

\section{Evaluation of EO activity on T. cruzi metacyclogenesis}

Epimastigotes at late log phase of growth (cell density of $5-7 \times 10^{7}$ cells $/ \mathrm{ml}$ ) were collected by centrifugation for $5 \mathrm{~min}$ at $7000 \mathrm{~g}$ at $10^{\circ} \mathrm{C}$, resuspended in triatomine artificial urine (TAU) medium at $5.0 \times 10^{8} \mathrm{cells} / \mathrm{ml}$ and kept at $28^{\circ} \mathrm{C}$ for $2 \mathrm{~h}$. Then, corresponding with nutritional stress, the cells were transferred to $25 \mathrm{~cm}^{2}$ bottles containing $5 \mathrm{ml}$ of TAU3AAG medium (final concentration of $5.0 \times 10^{6}$ cells $/ \mathrm{ml}$ ) with different concentration of $C$. verum EO $(4-145 \mu \mathrm{g} / \mathrm{ml})$ and incubated at $28^{\circ} \mathrm{C}$. After $24 \mathrm{~h}$, the relative number of epimastigotes and trypomastigotes was counted with a Neubauer chamber and used to calculate the percentage of differentiation. Mean inhibition of differentiation for each concentration (as compared with metacyclogenesis in untreated control cultures) was used to calculate the $\mathrm{IC}_{50} / 24 \mathrm{~h}$ using Microsoft Excel software by linear correlation. The experiment was performed in triplicate.

\section{Cytotoxicity}

Uninfected Vero cell monolayers were washed with PBS $\mathrm{pH} 7.2$, detached by treatment with $0.25 \%$ trypsin/0.1\% 
EDTA for 5 minutes at $37^{\circ} \mathrm{C}$, washed with RPMI medium $\mathrm{pH} 7.4+2.5 \% \mathrm{FCS}$, centrifuged at $0.2 \mathrm{~g}$ for $10 \mathrm{~min}$ at $4^{\circ} \mathrm{C}$ and resuspended in the same medium. Cell viability was assessed by Trypan Blue staining and the cells were seeded into 96-well plates $\left(2 \times 10^{4}\right.$ cells/well). After $24 \mathrm{~h}$, the cells were incubated with EOs or cinnamaldehyde at different concentrations $(25-1000 \mu \mathrm{g} / \mathrm{ml}$ for EOs; 0.26$39.64 \mu \mathrm{g} / \mathrm{ml}[2-300 \mu \mathrm{M}]$ for cinnamaldehyde). After $24 \mathrm{~h}$ of incubation, integrity of the cell monolayer was observed under an inverted microscope and $50 \mu \mathrm{l}$ of MTT (at $2 \mathrm{mg} / \mathrm{ml}$ in PBS) was added. After $4 \mathrm{~h}$ of incubation, absorbance was read at $550 \mathrm{~nm}$ with an ELx800 (BioTek) microplate reader. The mean of at least two independent experiments was used to plot a graph of inhibition $x$ concentration, which was used to calculate the $\mathrm{CC}_{50}(50 \%$ cytotoxic concentration) using Microsoft Excel software by linear correlation. Each experiment was performed in triplicate.

\section{Results}

An initial screening of all EOs was performed on T. cruzi epimastigotes, evaluating inhibitory activity at concentrations of $50 \mu \mathrm{g} / \mathrm{ml}$ and $300 \mu \mathrm{g} / \mathrm{ml}$. In this first trial, the EOs of Rosmarinus officinalis, Eucalyptus globulus, and Corymbia citriodora did not show activity at $300 \mu \mathrm{g} / \mathrm{ml}$ and were therefore not further evaluated.

Lower concentrations of the remaining EOs were then evaluated to estimate the $\mathrm{IC}_{50} / 24 \mathrm{~h}$ (Table 1$)$. The most effective $\mathrm{EO}$ was that of $C$. verum $\left(\mathrm{IC}_{50} / 24.13 \pm 1.13 \mu \mathrm{g} / \mathrm{ml}\right.$; $\left.\mathrm{IC}_{90} / 24 \mathrm{~h}=48.33 \mu \mathrm{g} / \mathrm{ml}\right)$, followed by $M$. frondosus $\left(\mathrm{IC}_{50} /\right.$ $24 \mathrm{~h}=60.87 \pm 1.13 \mu \mathrm{g} / \mathrm{ml})$, and $E$. uniflora $\left(\mathrm{IC}_{50} / 24\right.$ $\mathrm{h}=70 \pm 1.04 \mu \mathrm{g} / \mathrm{ml})$. The $\mathrm{IC}_{50} / 24 \mathrm{~h}$ of the reference drug benznidazole was $15.8 \pm 1.75 \mu \mathrm{g} / \mathrm{ml}(61 \mu \mathrm{M})$. Evaluation of cytotoxicity on Vero cells showed that the least cytotoxic EO was that of $C$. limon $\left(C_{50} / 24 \mathrm{~h}=281.69 \pm 1.12 \mu \mathrm{g} / \mathrm{ml}\right)$. EOs with higher selectivity indexes were those from $C$. limon (SI = 2.63), E. uniflora (2.46), M. frondosus (2.32), and C. verum (2.05), but all were more cytotoxic and less selective than benznidazole $\left(\mathrm{CC}_{50} / 24 \mathrm{~h}=147.37 \pm 1.22 \mu \mathrm{g} / \mathrm{ml}\right.$; $\mathrm{SI}=$ 9.33).

Since the $C$. verum EO was notably more effective on $T$. cruzi epimastigotes, it was selected for further evaluation on other developmental forms (trypomastigotes and amastigotes), as well as on the parasite differentiation process (metacyclogenesis). Metacyclogenesis was not significantly affected by $C$. verum EO at concentrations up to $15 \mu \mathrm{g} / \mathrm{ml}$. Higher concentrations led to reduction in percentage of trypomastigotes and metacyclogenesis was totally abolished with $25 \mu \mathrm{g} / \mathrm{ml}\left(\mathrm{IC}_{50} / 24 \mathrm{~h}=18.2 \pm 1.04 \mu \mathrm{g} / \mathrm{ml}\right)$. After $48 \mathrm{~h}$ of treatment with the $\mathrm{IC}_{50} / 24 \mathrm{~h}$ value, the surviving cells showed slower motion compared with the control. After treatment for $24 \mathrm{~h}$ with $35 \mu \mathrm{g} / \mathrm{ml}\left(2 \times \mathrm{IC}_{50} / 24 \mathrm{~h}\right)$ the few remaining cells (epimastigote forms) were motionless.

On purified metacyclic trypomastigotes, the estimated $\mathrm{IC}_{50} / 24 \mathrm{~h}$ was $5.05 \pm 1.03 \mu \mathrm{g} / \mathrm{ml}\left(\mathrm{IC}_{90}=8.21 \mu \mathrm{g} / \mathrm{ml}\right)$, showing that this form is more susceptible than epimastigotes. The selectivity index (SI) increased more than 4-fold as compared with epimastigotes (9.78 and 2.05, respectively).

Vero cells were first infected and then incubated with C. verum EO, to assure that the effect was on amastigote proliferation and not on adhesion/penetration of the trypomastigotes used in the infection. Treatment with $20 \mu \mathrm{g} / \mathrm{ml}$ reduced the number of total amastigotes by $50 \%$ when compared with control infection, resulting in an $\mathrm{IC}_{50} / 24 \mathrm{~h}$ value of $20 \mu \mathrm{g} / \mathrm{ml}$ (Table 2; Figures 1 and 2). The number of amastigotes $/ \mathrm{mm}^{2}$, the association index, and the percent inhibition (\%I) were also reduced by half, when compared with the untreated infection (Table 2). The mean number of amastigotes per cell decreased from 7.52 (untreated control) to 5.08 (Table 2; Figure 2).

GC-MS analysis identified five main constituents in $C$. verum $\mathrm{EO}$, the major constituents being $(E)$-cinnamaldehyde $(81.52 \%)$ and eugenol (16.68\%), followed by $(E)$ caryophyllene, (E)-cinnamyl acetate, and $\alpha$-humulene (Table 3). Since (E)-cinnamaldehyde was identified as the main constituent, it was further evaluated against T. cruzi epimastigotes and Vero cells, by the MTT colorimetric assay. However, it showed no activity or cytotoxicity at low concentrations up to $39.65 \mu \mathrm{g} / \mathrm{ml}(300 \mu \mathrm{M})$.

\section{Discussion}

Interest is growing in the search for natural compounds active against pathogenic trypanosomatids, resulting in several reports on the biological activity of essential oils (EOs) or their main constituents on these protozoa $[6,18-20]$. This activity is probably related to the function of EOs in nature, where they play a protective role in

Table 1 EO activity on $T$. cruzi ( $\left(\mathrm{C}_{50} / 24 \mathrm{~h}\right)$ epimastigotes and Vero cells $\left(\mathrm{CC}_{50} / 24 \mathrm{~h}\right)$

\begin{tabular}{cccc}
\hline Essential oil & $\mathbf{I C}_{\mathbf{5 0}}$ epimastigotes $(\boldsymbol{\mu \mathbf { g }} / \mathbf{m l})$ & $\mathbf{C C}_{\mathbf{5 0}}$ Vero cells $(\boldsymbol{\mu} \mathbf{g} / \mathbf{m l})$ & Selectivity index $(\mathbf{S I})$ \\
\hline Cinnamomum verum & $24.13 \pm 1.13$ & $49.4 \pm 1.12$ & 2.05 \\
Myrocarpus frondosus & $60.87 \pm 1.13$ & $141.3 \pm 1.14$ & 2.32 \\
Cymbopogon nardus & $94 \pm 1.14$ & $178.95 \pm 1.1$ & 1.90 \\
Citrus limon & $107.14 \pm 1.03$ & $281.69 \pm 1.12$ & 2.63 \\
Eugenia uniflora & $70 \pm 1.04$ & $172.42 \pm 1.15$ & 2.46 \\
Benznidazole (reference drug) & $15.8 \pm 1.75(61 \mu \mathrm{M})$ & $147.37 \pm 1.22$ & 9.33 \\
\hline
\end{tabular}


Table 2 Effect of C. verum EO on T. cruzi intracellular amastigotes after treatment for $24 \mathrm{~h}$

\begin{tabular}{|c|c|c|c|c|c|c|}
\hline & $\%$ Infected cells & Total intracellular amastigotes & Amastigotes/cell (mean) & Density amastigotes $/ \mathrm{mm}^{2}$ & $A I^{\mathrm{a}}$ & $\% l^{\mathbf{b}}$ \\
\hline Control & $59(n=5812)$ & 25746 & 7.52 & 42.7 & 442.5 & - \\
\hline $10 \mu \mathrm{g} / \mathrm{ml}$ & $51.8(n=5709)$ & 20315 & 6.87 & 33.7 & 355.87 & 21.1 \\
\hline $20 \mu \mathrm{g} / \mathrm{ml}$ & $50.6(n=4946)$ & 12717 & 5.08 & 21.1 & 257.05 & 50.61 \\
\hline
\end{tabular}

${ }^{\mathrm{a}}$ Association Index $(\mathrm{Al})=\%$ infected cells $\times$ amastigotes/cell.

$\mathrm{b}_{\%}$ Inhibition $(\% \mathrm{l})=100-(\mathrm{T} / \mathrm{C} \times 100)$, where $\mathrm{T}$ is the total number of intracellular amastigotes in treated cells and $\mathrm{C}$ is the total number of intracellular amastigotes in control cells.

plants, acting as antibacterial, antiviral, antifungal, and protection against herbivory [9].

We have here first screened the activity of different EOs on $T$. cruzi culture epimastigotes, which are easier to grow and thus represent a simple model for the identification of potential compounds active against this parasite. However, in vitro activity against $T$. cruzi epimastigotes does not guarantee promising activity against other forms of the parasite. In fact, a considerable number of plant extracts with positive inhibitory effects in vitro do not become alternative chemotherapies [28]. Therefore, a large number of EOs or their constituents and derivatives should be analyzed, until a promising molecule acting on different developmental stages of $T$. cruzi can be obtained.

Among the eight essential oils that we analyzed, the $C$. verum $\mathrm{EO}$ showed the most activity against $T$. cruzi epimastigotes. It has been shown that Cinnamomum sp. EO has antipyretic, antibacterial, antifungal, antiparasitic, and repellent activities [9,28-31]. However, despite its good inhibitory activity on $T$. cruzi, its $\mathrm{IC}_{50} / 24 \mathrm{~h}$ was still higher than that of the reference drug benznidazole, suggesting the need for high concentrations for in vivo studies. Nevertheless, it has been shown in treatment of mice that high concentrations of Cymbopogon citratus EO produce no toxic effects [32]. This finding indicates that EOs (or their main constituents) may have better activity in vivo than in vitro, with activity on parasitic infections and no cytotoxic activity [32,33]. Furthermore, treatment of mice with EOs showed beneficial effects not related to the parasite infection, such as reductions in plasma cholesterol [32]. Therefore, C. verum EO (or cinnamaldehyde derivatives) is a potential candidate in the search for trypanocidal chemotherapeutic drugs.

Although it did not have the best selectivity index (SI) on epimastigotes, the C. verum EO was effective at a concentration much lower than that of the other EOs that we evaluated. It was also effective on $T$. cruzi epimastigotes at concentrations lower than those previously obtained with EOs from Origanum vulgare (oregano), Thymus vulgaris (thyme), Achillea millefolium (yarrow), Syzygium aromaticum (clove), Ocimum basilicum (basil), and Cymbopogon citratus (lemon grass), or their main constituents [18-20]. Activity of the C. verum EO was also higher than that obtained with other EOs used against other pathogenic trypanosomatids [14,16,17,34].

On T. cruzi amastigotes, the C. verum EO was effective with $\mathrm{IC}_{50} / 24 \mathrm{~h}=20 \mu \mathrm{g} / \mathrm{ml}(\mathrm{SI}=2.47)$, a value similar to that found with epimastigotes. Its activity was better than that obtained with jacaranone (main constituent of Pentacalia desiderabilis), which showed no activity on intracellular amastigotes of $T$. cruzi and Leishmania chagasi at a concentration of $100 \mu \mathrm{g} / \mathrm{ml}$ [35]. However, the $\mathrm{IC}_{50} / 24 \mathrm{~h}$ value found here was four times higher than that obtained by Santoro and colleagues [18] with Cymbopogon citratus EO $\left(\mathrm{IC}_{50} / 24 \mathrm{~h}=5.1 \mu \mathrm{g} / \mathrm{ml}\right)$, although the SI was similar to that obtained with Lippia alba EO [36].

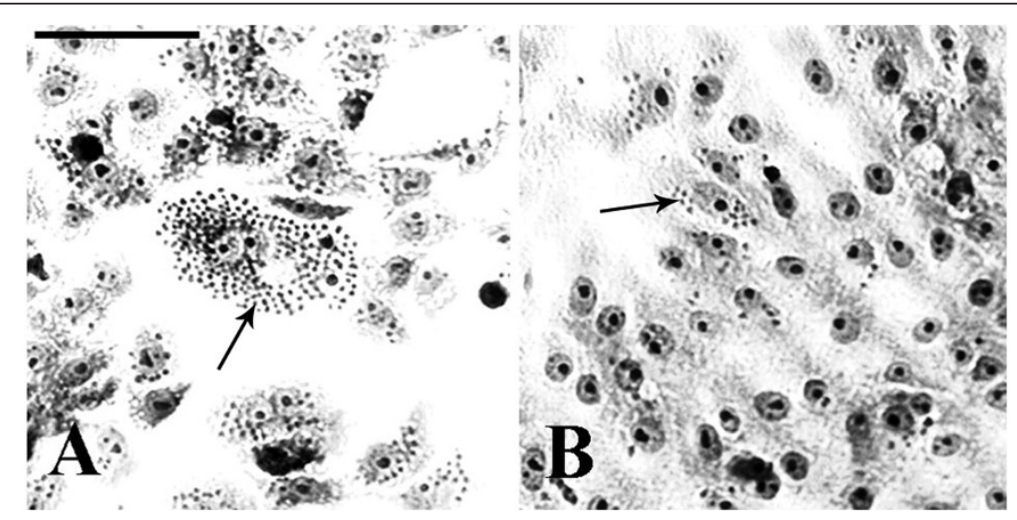

Figure 1 Vero cells infected with $T$. cruzi and then treated with C. verum essential oil (EO). (A) Control, without treatment; (B) Treatment for $24 \mathrm{~h}$ with $20 \mu \mathrm{g} / \mathrm{ml}$ C. verum EO. Note the decrease in amastigote (arrows) number after treatment. Bar $=100 \mu \mathrm{m}$. 


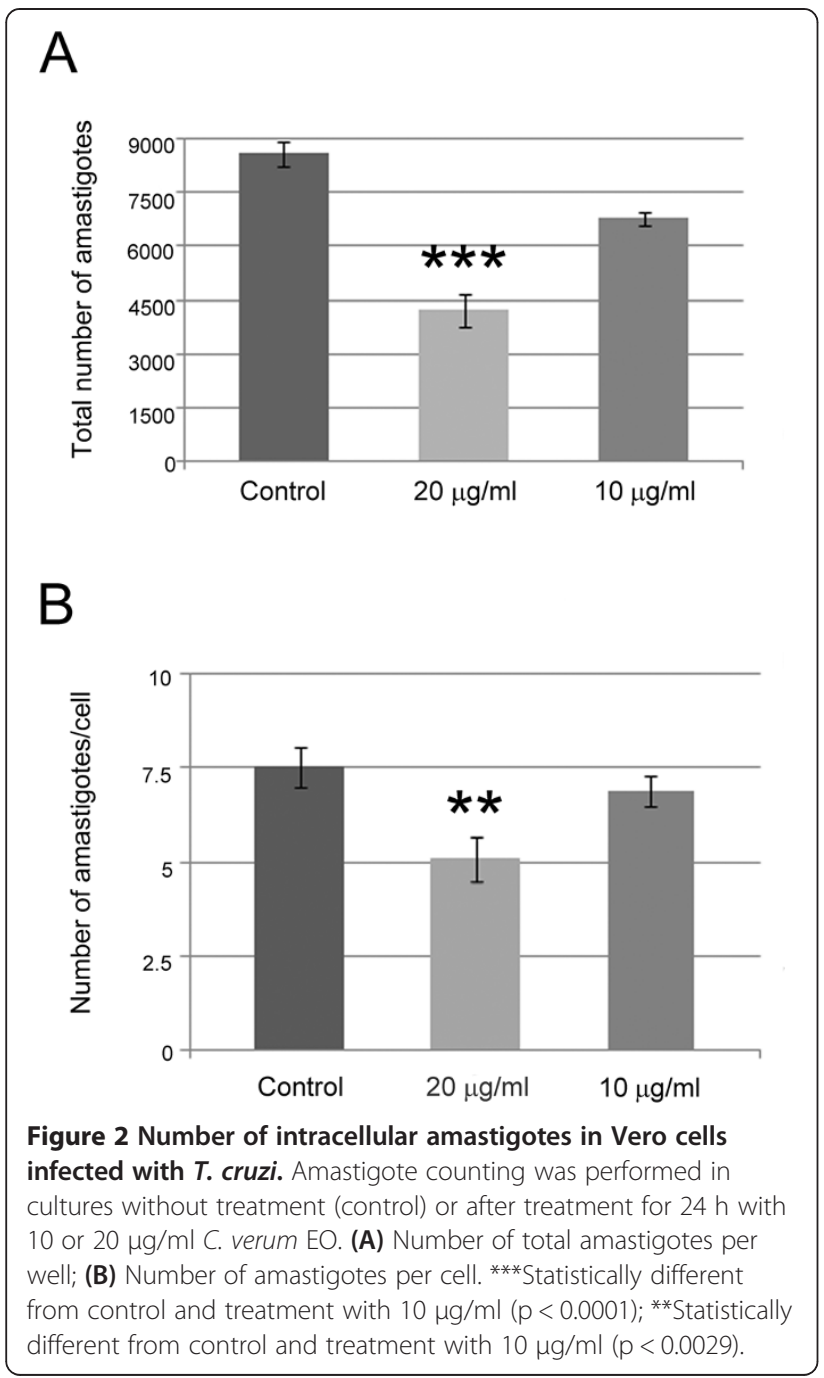

It has been shown that citral, the main constituent of Cymbopogon citratus EO, was able to inhibit differentiation of T. cruzi at a concentration of $30.8 \mu \mathrm{g} / \mathrm{ml}$ [37]. Our data showed that $C$. verum EO also interfered with metacyclogenesis of this parasite. The differentiation process was totally inhibited with $25 \mu \mathrm{g} / \mathrm{ml}$. At this concentration, only epimastigotes forms could be observed in the culture supernatant. Although it is possible that the EO was killing the trypomastigote forms, we cannot exclude the possibility that the inhibitory effect could be also due to killing of epimastigotes prior to the differentiation process, thus lowering the number of resulting trypomastigotes.

The C. verum EO presented higher activity on T. cruzi purified metacyclic trypomastigotes, increasing the SI to 9.78. This increase in SI, as compared with epimastigotes, has been already observed $[18,19]$. Such difference may be related to diverse metabolic pathways and membrane composition in the various developmental forms of T. cruzi. It is also possible that the composition of the different culture media used for the various forms of $T$. cruzi (LIT, RPMI-1640 and TAU3AAG media) may influence absorption and/or degradation of the EOs.

Several factors, such as part of the plant from which the EO was extracted and season of cultivation, can alter the composition of an EO and the concentrations of each constituent [9-38]. Eugenol and cinnamaldehyde have been reported as the main constituents in EOs of Cinnamomum spp. [30,39,40]. Accordingly, our analysis by $\mathrm{GC}-\mathrm{MS}$ of the $C$. verum $\mathrm{EO}$ used in our experiments also showed (E)-cinnamaldehyde (81.52\%) and eugenol $(16.68 \%)$ as main constituents.

Based on differences in the composition of the EO extracted from leaves of Cinnamomum osmophloeum, Cheng et al. (2006) [30] classified it into six chemotypes, according to the main component. The cinnamaldehyde and cinnamaldehyde/cinnamyl acetate types had the strongest antifungal activity, because of a higher concentration of cinnamaldehyde. Singh and colleagues (2007) [40] also attributed the antifungal effect of Cinnamomum zeylanicum EO to the high concentration of cinnamaldehyde. The $C$. verum EO that we investigated had mostly cinnamaldehyde in its composition, which suggests that its activity could be related to this component. However, (E)-cinnamaldehyde was not effective against $T$. cruzi epimastigotes at low concentrations up to $300 \mu \mathrm{M}$ $(39.648 \mu \mathrm{g} / \mathrm{ml})$. (E)-cinnamaldehyde was active against $T$. brucei trypomastigotes $\left(\mathrm{IC}_{50}=2.93 \mu \mathrm{g} / \mathrm{ml}\right.$ [41]), which indicates different susceptibilities among different pathogenic trypanosomatids and different developmental forms.

The tetrazolium dye MTT can be used to measure cytotoxicity (loss of viable cells: trypanocidal) or cytostatic activity (trypanostatic) of potential drugs. MTT reduction occurs via $\mathrm{NAD}(\mathrm{P}) \mathrm{H}$-dependent oxidoreductase enzymes

Table 3 Cinnamomum verum EO constituents by GC-MS analysis

\begin{tabular}{lllll}
\hline Constituent & Retention time & Concentration (\%) & RI calc & RI lit \\
\hline (E)-cinnamaldehyde & 20.115 & 81.52 & 1282 & 1267 \\
eugenol & 23.713 & 16.68 & 1366 & 1356 \\
(E)-caryophyllene & 26.274 & 1.19 & 1426 & 1417 \\
(E)-cinnamyl acetate & 27.280 & 0.01 & 1450 & 1443 \\
a-humulene & 27.709 & 0.12 & 1460 & 1452 \\
\hline
\end{tabular}

RI calc: Retention Index calculated; RI lit: Retention Index from the literature [24]. 
located largely in the cytosolic compartment of the cell $[42,43]$. MTT reduction is associated not only with mitochondria, but also with the cytoplasm and with non-mitochondrial membranes including the endosome/lysosome compartment and the plasma membrane [42]. Thus, low optical density of MTT staining can indicate low metabolic activity (trypanostatic) or low number of cells (trypanocidal). In our experiments, all plates were observed in inverted microscope before the MTT assay, to assess possible EO activity. In these observations we could see fewer cells and increased cellular debris (as compared with the untreated control) with increasing EO concentration (data not shown). Therefore, our data indicate that C. verum $\mathrm{EO}$ has a trypanocidal effect.

Activity of cinnamon EO could be associated with the lipophilic characteristic of its constituents. As typical lipophilic molecules, they cross the cell membrane and once inside the cells, cinnamaldehyde could interact with a variety of proteins, forming covalent bonds with amino acid residues, inactivating enzymes, and affecting a number of cellular activities. The mode of action against $T$. cruzi could be via addition of an aldehyde thiol to sulfur-containing components in the key enzymes trypanothione and trypanothione reductase [41], which would lead to a redox imbalance (detected by the MTT assay). Therefore, it is possible that C. verum EO acts inside trypanosomes by promoting redox imbalance in the cytosol.

\section{Conclusions}

Biological activity of eight different essential oils was screened against Trypanosoma cruzi epimastigotes. The essential oils of C. verum, $M$. frondosus, and E. uniflora showed the best activity and are promising agents that deserve further study. C. verum essential oil was effective on the three developmental forms of T. cruzi (epimastigotes, trypomastigotes, and amastigotes) and on the in vitro differentiation of this parasite. C. verum essential oil was as effective as, or more effective than, other essential oils or their main constituents tested on trypanosomatids. Evaluation of cinnamaldehyde derivatives is as a potential strategy for further studies to find increased selectivity on $T$. cruzi and identification of the mode of action against this parasite.

\section{Competing interests}

The authors declare that they have no competing interests.

\section{Authors' contributions}

CMOA carried out the biological evaluation on T. cruzi and Vero cells and drafted the manuscript. TGS and BHLNSM acquired and analyzed the GC-MS data. MJS conceived the study, participated in its design and edited the final version of the manuscript. All authors had approved the final manuscript.

\section{Acknowledgements}

This work was supported by Conselho Nacional de Desenvolvimento Científico e Tecnológico (CNPq) and Fundação Oswaldo Cruz (Fiocruz). The authors thank the Laboratory of Natural Products and Chemical Ecology in the Department of Chemistry at the Federal University of Paraná (UFPR), Curitiba-PR, Brazil, for the GC-MS analysis. The authors also thank the Program for Technological Development in Tools for Health (PDTIS)-FIOCRUZ for use of the RPT07C-Confocal Microscopy Facility at Carlos Chagas Institute/Fiocruz, Curitiba-PR, Brazil).

\section{Author details}

${ }^{1}$ Laboratory of Cell Biology, Carlos Chagas Institute/Fiocruz, Rua Prof. Algacyr Munhoz Mader 3775, Cidade Industrial, 81350-010 Curitiba, PR, Brazil.

'Laboratory of Natural Products and Chemical Ecology, Department of Chemistry, Federal University of Paraná (UFPR), 81.531-990 Curitiba, PR, Brazil.

Received: 24 January 2014 Accepted: 20 August 2014

Published: 22 August 2014

\section{References}

1. World Health Organization (WHO): Chagas disease (American trypanosomiais) fact sheet $n^{\circ} 340$, updated March 2014. [http://www. who.int/mediacentre/factsheets/fs340/en/]. Accessed August 06, 2014.

2. Urbina JA: Specific chemotherapy of Chagas disease: relevance, current limitations and new approaches. Acta Trop 2010, 115:55-68.

3. Coura JR: Chagas disease: what is known and what is needed. A background article. Mem Inst Oswaldo Cruz 2007, 102:113-122.

4. Teixeira AR, Nitz N, Guimaro MC, Gomes C, Santos-Buch CA: Chagas disease. Postgrad Med J 2006, 82:788-798.

5. Coura JR: Present situation and new strategies for Chagas disease chemoteraphy- a proposal. Mem Inst Oswaldo Cruz 2009, 104:549-554.

6. Alviano DS, Barreto ALS, Dias FA, Rodrigues IA, Rosa MSS, Alviano CS, Soares RMA: Conventional therapy and promising plant-derived compounds against trypanosomatid parasites. Front Microbiol 2012, 3:283.

7. Schmidt TJ, Khalid SA, Romanha AJ, Alves TM, Biavatti MW, Brun R, Da Costa FB, de Castro SL, Ferreira VF, de Lacerda MV, Lago JH, Leon LL, Lopes NP, das Neves Amorim RC, Niehues M, Ogungbe IV, Pohlit AM, Scotti MT, Setzer WN, de N C Soeiro M, Steindel M, Tempone AG: The potential of secondary metabolites from plants as drugs or leads against protozoan neglected diseases - part I. Curr Med Chem 2012, 19(Suppl 14):2128-2175.

8. Wink M: Medicinal plants: a source of anti-parasitic secondary metabolites. Molecules 2012, 17:12771-12791.

9. Bakkali F, Averbeck S, Averbeck D, Idaomar M: Biological effects of essential oils - A review. Food Chem Toxicol 2008, 46:446-475.

10. Bassolé $I H N$, Juliani HR: Essential oils in combination and their antimicrobial properties. Molecules 2008, 17:3989-4006.

11. Hammer KA, Carson CF, Riley TV: Antimicrobial activity of essential oils and other plant extracts. J Appl Microbiol 1999, 86:985-990.

12. Lima IO, Oliveira RAG, Lima EO, Farias NMP, De Souza EL: Atividade antifúngica de óleos essenciais sobre espécies de Candida. Rev Bras Farmacogn 2006, 16:197-201.

13. York T, van Vuuren SF, de Wet H: An antimicrobial evaluation of plants used for the treatment of respiratory infections in rural Maputaland, KwaZulu-Natal, South Africa. J Ethnopharmacol 2012, 144:118-127.

14. Habila N, Agbaju AS, Ladan Z, Bello IA, Haruna E, Dakare MA, Atolagbe TO: Evaluation of in vitro activity of essential oil against Trypanosoma brucei brucei and Trypanosoma evansi. J Parasitol Res 2010, 2010:534601.

15. Misra P, Kumar A, Khare P, Gupta S, Kumar N, Dube A: Pro-apoptotic effect of the landrace Bangla Mahoba of Piper betle on Leishmania donovani may be due to the high content of eugenol. J Med Microbiol 2009, 58:1058-1066

16. Medeiros MGF, Silva AC, Citó AMGL, Borges AR, Lima SG, Lopes JAD, Figueiredo RCBQ: In vitro antileishmanial activity and cytotoxicity of essential oil from Lippia sidoides Cham. Parasitol Int 2011, 60:237-241.

17. Oliveira VCS, Moura DMS, Lopes JAD, Andrade PP, Silva NH, Figueiredo RCBQ: Effect of the essential oils from Cympobogon citratus (DC) Stapf., Lippia sidoides Cham., and Ocimum gratissimum L. on growth and ultrastructure of Leishmania chagasi promastigotes. Parasitol Res 2008, 104:1053-1059.

18. Santoro GF, Cardoso MG, Guimarães LGL, Freire JM, Soares MJ: Antiproliferative effect of the essencial oil of Cymbopogon citratus (DC) Stapf 
(lemongrass) on intracelular amastigotes, bloodstream trypomastigotes and culture epimastigotes of Trypanosoma cruzi (Protozoa: Kinetoplastida). Parasitology 2007, 13:1649-1656.

19. Santoro GF, Cardoso MG, Guimarães LGL, Mendonça LZ, Soares MJ: Trypanosoma cruzi: activity of the essential oils from Achilea milefolium L., Syzygium aromaticum L. and Ocimum basilicum L. on epimastigotes and trypomastigotes. Exp Parasitol 2007, 116:283-290.

20. Santoro GF, Cardoso MG, Guimarães LGL, Salgado APSP, Menna-Barreto RFS, Soares MJ: Effect of oregano (Origanum vulgare L.) and thyme (Thymus vulgaris L.) essential oils on Trypanosoma cruzi (Protozoa: Kinetoplastida) growth and ultrastructure. Parasitol Res 2007, 100:783-790.

21. Santos KKA, Matias EFF, Tintino SR, Souza CES, Braga MFBM, Guedes GMM, Rolón M, Veja C, Arias AR, Costa JGM, Menezes IRA, Coutinho HDM: Anti-Trypanosoma cruzi and cytotoxic activities of Eugenia uniflora L. Exp Parasitol 2012, 131:130-132

22. Ueda-Nakamura T, Mendonça-Filho RR, Morgado-Díaz JA, Maza PK, Prado Dias Filho B, Cortez DAD, Alviano DS, Rosa MS, Lopes AH, Alviano CS, Nakamura CV: Antileishmanial activity of eugenol-rich essential oil from Ocimum gratissimum. Parasitol Int 2006, 55:99-105.

23. Guimarães LGL, Cardoso MG, Zacaroni LM, Lima RK, Pimentel F, Morais AR: Influência da luz e da temperatura sobre a oxidação do óleo essencial de capim-limão (Cymbopogon citratus (D.C.) STAPF). Quim Nova 2008, 31:1476-1480.

24. Adams RP: Identification of Essential oil Components by Gas Chromatography/ Mass Spectroscopy. 4th edition. IL, USA: Edited by Allured Publishing Corporation; 2007

25. Contreras VT, Salles JM, Thomas N, Morel CM, Goldenberg S: In vitro differentiation of Trypanosoma cruzi under chemically defined conditions. Mol Biochem Parasitol 1985, 16:315-327.

26. Guru PY, Agrawi AK, Singha UK, Singhal A, Gupta CM: Drug targeting in Leishmania donovani infections using tuftsin-bearing liposomes as drug vehicles. FEBS Lett 1989, 245:204-208.

27. Lakshmi V, Pandey K, Kapil A, Singh N, Samant M, Dube A: In vitro and in vivo leishmanicidal activity of Dysoxylum bicnectariferum and its fractions against Leishmania donovani. Phytomedicine 2007, 14:36-42.

28. Lirussi D, Li J, Prieto JM, Gennari M, Buschiazzo H, Rios JL, Zaidenberg A: Inhibition of Trypanosoma cruzi by plant extracts used in chinese medicine. Fitoterapia 2004, 75:718-723.

29. Anthony JP, Fyfe L, Smith H: Plant active components - a resource for antiparasitic agents? Trends Parasitol 2005, 21:462-468.

30. Cheng SS, Liu JY, Hsui YR, Chang ST: Chemical polymorphism and antifungal activity of essential oils from leaves of different provenances of indigenous cinnamon (Cinnamomum osmophloeum). Bioresource Technol 2006, 97:306-312.

31. Kalemba D, Kunicka A: Antibacterial and antifungal properties of essential oils. Curr Med Chem 2003, 10:813-829.

32. Costa CAR, Bidinotto LT, Takahira RK, Salvadori DMF, Barbisan LF, Costa M: Cholesterol reduction and lack of genotoxic or toxic effects in mice after repeated 21-day oral intake of lemongrass (Cymbopogon citratus) essential oil. Food Chem Toxicol 2011, 49:2268-2272.

33. Arruda DC, Miguel DC, Yokoyama-Yasunaka JKU, Katzin AM, Uliana SRB: Inhibitory activity of limonene against Leishmania parasites in vitro and in vivo. Biomed Pharmacother 2009, 6:643-649.

34. Parreira NA, Magalhães LG, Morais DR, Caixeta SC, Sousa JPB, Bastos JK, Cunha WR, Silva MLA, Nanayakkara NPD, Rodrigues V, Silva Filho AA: Antiprotozoal, schistosomicidal, and antimicrobial activities of the essential oil from the leaves of Baccharis dracunculifolia. Chem Biodivers 2010, 7:1-10.

35. Morais TR, Romoff P, Fávero A, Reimão JQ, Lourenço WC, Tempone AG, Histov AD, Santi SM, Lago JHG, Sartorelli P, Ferreira MJP: Anti-malarial, anti-trypanosomal and anti-leishmanial activities of jacaranone isolated from Pentacalia desiderabilis (Vell.) Cuatrc. (Asteraceae). Parasitol Res 2012, 110:95-101

36. Escobar $P$, Leal SM, Herrera LV, Martinez JR, Stashenko E: Chemical composition and antiprotozoal activities of Colombian Lippia spp essential oils and their major components. Mem Inst Oswaldo Cruz 2010, 105:184-190.

37. Cardoso J, Soares MJ: In vitro effects of citral on Trypanosoma cruzi metacyclogenesis. Mem Inst Oswaldo Cruz 2010, 105:1026-1032.

38. Victoria FN, Lenardão EJ, Savegnago L, Perin G, Jacob RG, Alves D, Da Silva WP, Motta AS, Nascente OS: Essential oil of the leaves of Eugenia uniflora
L.: antioxidant and antimicrobial properties. Food Chem Toxicol 2012, 50:2668-2674

39. Jayaprakasha GK, Mohan Rao $\sqcup$, Sakariah KK: Volatile constituents from Cinnamomun zeylanicum fruit stalks and their antioxidant activities. J Agric Food Chem 2003, 51:4344-4348.

40. Singh G, Maurya S, Lampasona MP, Catalan CAN: A comparison of chemical, antioxidant and antimicrobial studies of cinnamon leaf and bark volatile oils, oleoresins and their constituents. Food Chem Toxicol 2007, 45:1650-1661.

41. Nibret E, Wink M: Trypanocidal and antileukaemic effects of the essentia oils of Hagenia abyssinica, Leonotis ocymifolia, Moringa stenopetala, and their main individual constituents. Phytomedicine 2010, 17:911-920.

42. Berridge MV, Herst PM, Tan AS: Tetrazolium dyes as tools in cell biology: new insights into their cellular reduction. Biotechnol Annu Rev 2005, 11:127-152.

43. Berridge MV, Tan AS: Characterisation of the cellular reduction of 3-(4,5dimethylthiazol-2yl)-2,5-diphenyltetrazolium bromide (MTT): subcellular localization, substrate dependence, and involvement of mitochondrial electron transport in MTT reduction. Archives Biochem Biophys 1993, 303:474-482.

\section{doi:10.1186/1472-6882-14-309}

Cite this article as: Azeredo et al:: In vitro biological evaluation of eight different essential oils against Trypanosoma cruzi, with emphasis on Cinnamomum verum essential oil. BMC Complementary and Alternative Medicine 2014 14:309.

\section{Submit your next manuscript to BioMed Central and take full advantage of:}

- Convenient online submission

- Thorough peer review

- No space constraints or color figure charges

- Immediate publication on acceptance

- Inclusion in PubMed, CAS, Scopus and Google Scholar

- Research which is freely available for redistribution 